\title{
Risk factors associated with cystic ovarian disease in Norwegian dairy cattle
}

\author{
Sindre T Nelson", Adam D Martin, Olav Østerås
}

\begin{abstract}
Background: The aims of this study were to establish the incidence of cystic ovarian disease (COD) and its geographical and seasonal variation in Norway, investigate the effect of COD on culling rates, and describe the effects of COD on subsequent reproductive performance and its association to twins.

Methods: Diagnosis of COD was made by veterinary surgeons in the field. Four statistical models were made all including herd as random effect: The four different dependent variables investigated were: 1 ) Diagnosis of COD between 40 and 165 days in milk or not; $(n=511,657) ; 2)$ Twins or singleton; data restricted to lactations with new calving ( $n=156,661)$ : 3 ) Culling/removal or not $(n=573,184)$ : 4) Culling due to reproductive problems; data included only lactations which ended in culling $(n=234,232)$. Model 1,3 and 4 applied Cox regression models, and model 2 logistic regression. Independent variables were parity, twins/singletons, calving season, herd size, region, COD occurrence in present lactation (if not dependent), and COD diagnosis in previous lactation.

Results: The incidence was $0.82 \%$ per lactation. COD increased with increasing parity, was smallest at herd size between 35 and 85 cows. Cows in $1^{\text {st }}$ parity and calved in spring had lowest hazard of COD and hazard for COD diagnosis was highest in autumn with $\mathrm{HR}=2.6(1.9-3.4)$ compared to spring. There was an interaction between parity and season. COD incidence was lower south of $60^{\circ} \mathrm{N}$. Cows which experienced COD had an increased odds of giving birth to twins $O R=2.2(1.7-2.7)$. Of those that were culled, those with COD were culled more frequently because of reproductive problems; HR $=2.1$ (1.9 - 2.3) for higher parity than 2. Having COD diagnosed in the preceding lactation was a hazard for diagnosis in the lactation studied.

Conclusion: COD diagnosis is strongly associated with season (autumn calving) and parity. Herds north of $60^{\circ} \mathrm{N}$ have more COD. Occurrence of COD is associated with twin births as well as culling due to reproduction.
\end{abstract}

\section{Background}

Poor reproductive performance is one of the greatest causes of economic loss in dairy cattle production worldwide. Cystic ovarian disease (COD) is a cause of temporary infertility and one of the most common reproductive disorders in dairy cows with a reported incidence of 6 to 23\% [1-6]. A meta-analysis published in 1999 showed that COD was associated with a 6 to 11 day increase in the calving to first service interval, and a 20 to 30 day increase in the calving to pregnancy interval [7]. It is also known to increase the risk of culling $[8,9]$. The economic impact of COD was calculated in 1986 to be $\$ 137$ per case; but national, regional and seasonal variations were large [9]. A Swedish study found a

\footnotetext{
* Correspondence: sindre.nelson@nvh.no

Department of Production Animal Clinical Sciences, Norwegian School of Veterinary Science, Oslo, Norway
}

case of COD decreased the net return between 470,and 720,- SEK per cow per lactation [8]. It is economically beneficial to treat COD [10].

A number of cow level factors have been associated with an increased risk of COD. These include parity, constitutional weakness, body condition score, and genetic factors $[4,5,11]$. Milk yield has been identified as a risk factor in some studies but not in others. It is likely that this effect is dependent on the energy status of the cow, rather than the milk yield per se. High milk yield may contribute to negative energy balance which, when severe, results in metabolic and hormonal adaptations which influence follicle growth and cyst development [12]. Occurrence of COD predisposes an animal to COD in the following lactation [11]. Several studies have found that COD is associated with twinning [13-15]. 
Environmental factors including nutrition, feeding management, and housing type, are associated with risk of COD $[12,16]$. A seasonal effect on COD incidence has been identified. A study performed in North-East Spain $\left(40^{\circ} \mathrm{N}\right)$ showed that cows calving in the summer are 2.6 times more likely to develop COD than cows calving in the winter, it attributed the difference to the seasonal variation of heat stress [11]. A Norwegian study found that both photo intensity and photoperiod were associated with reproductive performance [17]. Norway's latitude is between $58^{\circ} \mathrm{N}$ to $71^{\circ} \mathrm{N}$ and its climate much colder than that of North-East Spain. It is, therefore, reasonable to investigate geographical and seasonal variation of COD incidence in these different conditions.

Despite COD being a well known reproductive disorder, there is little new field data on its incidence and effects on reproduction, and there is still a discussion about which risk factors are predisposing [12]. The last population level study in the Nordic countries was performed over 20 years ago [18]. Therefore, the aims of this study were to: i) establish the incidence of COD for Norwegian Red cattle and its geographical and seasonal variation; ii) investigate the effect of COD on culling rates; and iii) describe the effects of COD on subsequent reproductive performance and association with twinning.

\section{Methods}

\section{Study population}

Data on the study population were extracted from all herds (approximately 15,000) which were members of the Norwegian Dairy Health Recording System (NDHRS) in the years 2005, 2006, 2007 and 2008. The Norwegian dairy population consists of $94 \%$ purebred Norwegian Red cattle. All other breeds were excluded from this study. All lactations starting with a calving during 2006 and 2007 were extracted including calving date (starting day), date of subsequent calving or date of removal from the herd. Lactation length was estimated as the distance from each calving until 15 days before the next calving or removal from the herd. If the lactation length was more than 516 days, that lactation was excluded. The number of included lactations was 579,722 .

All recordings of COD were merged into the lactation in which they occurred. Each COD event, and day of diagnosis, was numbered from one onward according to the number of days in milk (DIM). Additionally, COD events in the previous lactation were merged into this dataset. In the same dataset, all service data were merged with the corresponding lactation and numbered according to DIM. Other variables included, and used in this study, were number of calves born, dystocia, date of birth, farm identity, date of culling, primary and secondary given reason for culling and breed.

\section{Case definition}

The definition of COD in this paper is a diagnosis of COD that has been recorded on the animal's health card in the NDHRS made by practicing veterinary surgeons during their regular field work. This could have been a scheduled examination, in a reproductive herd health programme, or because the farmer wanted a specific cow examined. The NDHRS has been in place for more than 30 years and has been evaluated by Østerås et al. (2007) [19]. In this study COD was diagnosed according to guidelines from the Norwegian Cattle Health Services (NCHS) which defines COD as a "follicle-like structure identified by rectal palpation with a diameter of at least $2.5 \mathrm{~cm}$ in the absence of luteal tissue".

\section{Time to event calculations}

Calving season was grouped into four classes; spring (March, April and May), summer (June, July and August), autumn (September, October and November) and winter (December, January and February). Each herd was categorised into one of 3 geographic areas according to the placement south-north (roughly according to latitude limit $60^{\circ} \mathrm{N}, 65^{\circ} \mathrm{N}$ and $70^{\circ} \mathrm{N}$ ).

The distance from calving to COD diagnosis and between COD diagnoses within the same lactation were calculated. In addition, the time from calving to breeding, the time COD diagnoses to breeding, as well as between breeding intervals within the same lactation were calculated.

\section{Statistical analysis}

Extracted data were analysed in SAS, version 9.1.3 (SAS Institute INC., Cary, NC). Calculation of descriptive statistics was performed using Proc Means or Proc Univariate. The distribution of data was evaluated using statistical and graphical methods. Possible correlations between variables were assessed by Chi-square for class variables, and simple regression for continuous variables.

Four multivariable models were made with presence or absence of COD diagnosis, twins at next calving, culling during lactation and reproduction given as reason for culling when culled, respectively as dependant variables. The models with COD, culling during lactation and reproduction given as reason for culling were constructed using Cox regression models applying Proc Phreg in SAS. The model with the dependant variable twins or not applied logistic regression using Proc Genmod.

In the model analysing COD as dependent variable, all lactations which ended with culling before 40 DIM, or those having COD diagnosed before 40 DIM, were excluded. The observation time ended at first event of COD, and lactations were censored at culling or at 165 
DIM if not culled yet. Thus, a cow which first experienced COD after 165 DIM was classified as not having COD in this model. The time interval of 40 to 165 DIM was chosen as it covers the $10^{\text {th }}$ and $90^{\text {th }}$ percentiles from calving to first diagnosis for $>2^{\text {nd }}$ parity and $1^{\text {st }}$ parity, respectively (Table 1). Lactations which began with the calving defined observation time in this analysis started at Day 40. The final model contained 3,913 events of COD within 511,657 lactations from 14,405 herds. The model was:

Model 1: $\lambda\left(t ; Z_{\mathrm{ki}}\right)=\lambda_{0}(t) \mathrm{e}^{\beta^{\prime} \mathrm{Z} k i(t)}$; where $\lambda_{0}(t)$ is an arbitrary baseline hazard function, $\beta$ is the vector of regression coefficients; $Z_{k i}(t)$ is the covariate process associated with the $\mathrm{k}^{\text {th }}$ lactation of the $\mathrm{i}^{\text {th }}$ herd. The $\beta$ is estimated by the maximum partial likelihood under the independent working assumption, and uses a robust sandwich covariance estimate to account for the intracluster dependence, as described by Lee et al. [20]. The tested independent variables included in the $\beta$ vector were parity $(1,2,>2)$, herd size $(<35,35-84,>84$ cows $)$, calving season (four categories: spring $=$ March, April and May; summer = June, July and August; autumn = September, October and November; winter $=$ December, January and February), twins or singleton at birth (start of lactation), region in Norway was divided in three according to county borders fitting approximately at latitudes 60 and $65^{\circ} \mathrm{N}$ (south of $60^{\circ} \mathrm{N}$; middle - between $60^{\circ} \mathrm{N}$ and $65^{\circ} \mathrm{N}$; and north between $65^{\circ} \mathrm{N}$ and $70^{\circ} \mathrm{N}$ ), as well as interactions between parity and calving season, and calving season and geographic region. Herd size was transformed into a class variable after identifying the parable shape of the association with a minimum between 35 to 85 cows in the herd. All class variables were transformed to separate class variables with parity 1 , spring calving, herd size 35 to 85 cows, region South of $60^{\circ} \mathrm{N}$ as reference group. Including parity and season as interaction calving in spring at $1^{\text {st }}$ parity was made

Table 1 The occurrence of cystic ovarian disease in days after calving stratified by parity

\begin{tabular}{llllllll}
\hline Parity & Time interval & $\mathbf{n}$ & \multicolumn{5}{c}{ Distribution in days } \\
\cline { 3 - 8 } & & $\mathbf{1 0 \%}$ & $\mathbf{2 5 \%}$ & median & $\mathbf{7 5 \%}$ & $\mathbf{9 0 \%}$ \\
\hline $1^{\text {st }}$ & $\begin{array}{l}\text { Calving to } 1^{\text {st }} \\
\text { diagnosis }\end{array}$ & 845 & 49 & 70 & 93 & 124 & 164 \\
$2^{\text {nd }}$ & & 1251 & 43 & 60 & 83 & 113 & 144 \\
$>2^{\text {nd }}$ & & 2662 & 40 & 56 & 76 & 106 & 139 \\
$1^{\text {st }}$ & Calving to $2^{\text {nd }}$ & 79 & 72 & 99 & 123 & 157 & 214 \\
& diagnosis & & & & & & \\
$2^{\text {nd }}$ & & 93 & 78 & 87 & 109 & 142 & 204 \\
$>2^{\text {nd }}$ & & 279 & 62 & 78 & 100 & 128 & 158 \\
$1^{\text {st }}$ & $1^{\text {st }}$ to $2^{\text {nd }}$ diagnosis & 79 & 5 & 11 & 18 & 33 & 63 \\
$2^{\text {nd }}$ & & 93 & 10 & 11 & 18 & 33 & 63 \\
$>2^{\text {nd }}$ & & 279 & 10 & 13 & 21 & 32 & 58 \\
\hline
\end{tabular}

reference in the final model. COD in previous lactation and lactation starting with twins or singleton was also tested in the model. Independent variables or interaction terms with $P$-value $>0.05$ were excluded from the model by the backward elimination procedure. The model fit was evaluated by plotting the deviance residuals against the covariates [21]. To test for the proportional hazard assumption, the log of the negative log of survival was plotted against time with most important independent variable as strata.

The model for estimating the probability of twins versus singleton was made from a sub-dataset including 156,661 lactations which ended in a new calving and this calving had a singleton or twins $(n=5,212)$. The model constructed was:

Model 2: $\operatorname{logit}\left(\mathrm{TWINS}_{\mathrm{i}}\right)=\beta_{0}+\beta_{1}{ }^{*} \operatorname{parity}_{\mathrm{i}}+\beta_{3}{ }^{*}\left(\mathrm{X}_{1 \mathrm{i}}\right)+\ldots$ $+\beta_{\mathrm{k}}{ }^{*}\left(\mathrm{X}_{\mathrm{ki}}\right)+\mu_{\text {herd }(\mathrm{i})}$

The tested independent variables were the same as Model 1 in addition to twins, singleton or other remarks at birth (start of lactation) and COD diagnosis, or not, during the lactation. Variables with $P$-values $>0.05$ were excluded from the model. Herd identity was introduced as random effect to adjust for correlated observation within each herd. This was done by implementing alternating logistic regression [22].

Model 3, the model for estimating the probability of removal versus remained in the herd (calved again), was estimated using a subset of the main dataset. This subset included 573,184 lactations that ended in calving or removal. Number of removals was 234,232 corresponding to $40.9 \%$. These lactations were within 14,572 different herds. The model constructed was the same as the Cox regression model, Model 1. However, the dependant variable in Model 3 was time from calving until culling. Lactations not ending in culling were censored at the earliest of; the cow was sold as live animal, or the farmer ended the membership of NDHRS, or latest at 350 DIM. Intra-cluster dependence within herd was adjusted for using the procedure described for Model 1. Due to the non-proportional hazard in different parities, the model had to be run separately for parity 1,2 and > 2 , respectively. The tested independent variables were the same as for Model 1, including also COD diagnosis during lactation or not. Variables with $P$-values $>0.05$ were excluded from the model. However, occurrence of COD was forced into the model.

The model for the probability of removal due to reproductive problems of those lactations ending in removal from the herd, versus the lactations ending in removal from reasons other than reproduction, was estimated using a subset of the main dataset. A total of 234,232 lactations were included, of which 35,827 (corresponding to $15.3 \%$ ) was due to reproduction problems. These lactations were within 14,515 different herds. 
The model constructed was the same model as Model 1, however using time from calving until culling due to reproductive problems as dependent variable. Lactations not ending in culling due to reproductive problems were censored at the time the cow culled due to other reasons or at 350DIM, whatever came first. However, all cows were culled during the lactation of study. Intracluster dependence within herd was adjusted for using the procedure described for Model 1. Due to non-proportional hazard in different parities in culling hazard and different association to COD, the model had to be run separately for parity 1, 2 and $>2$, respectively. The tested independent variables were the same as in Model 3. Variables with $P$-value $>0.05$ were excluded from the model.

\section{Results}

Data were available from 14,572 herds with mean herd size of 17.9 cow years. The general production level was 6,388 kg milk pr cow year in 2006 and 6,543 kg milk per cow year in 2007. The parity distribution was; $1^{\text {st }}$ parity: $36.9 \%, 2^{\text {nd }}: 26.7 \%, 3^{\text {rd }}: 17.2 \%, 4^{\text {th }}: 9.9 \%$, $>4^{\text {th }}$ : 9.3\%. The mean lactation length was 303 days (SD 121 days), whilst the median lactation length was 347 days.

In total, 4758 lactations had one or more COD registrations (incidence $0.82 \%$ ). The percentage of lactations with COD diagnosis prior to birth of a singleton calf was 0.83 , and prior to the birth of twin calves 1.08 . None of the 45 lactations that began with the birth of triplets had COD diagnosed in the previous lactation. The majority of COD containing lactations had a single COD occurrence $(89.3 \%, \mathrm{n}=4249)$. However, 451 animals $(9.5 \%)$ had a $2^{\text {nd }}, 49$ animals $(1.0 \%)$ a $3^{\text {rd }}$, and 9 $(0.2 \%)$ animals had a $4^{\text {th }}$ COD registration within the same lactation. For cows with no records of COD during lactation the mean calving to first service interval was 81 days, with $90 \%$ occurring between 41 and 142 days. For cows which experienced COD during the lactation the mean calving to first service interval was 87 days, with $90 \%$ occurring between 42 and 150 days.

In total $55.6 \%$ of the cows that were diagnosed with COD began a new lactation, compared to $59.2 \%$ that did not have COD. Of the cows that calved again, and did not have COD, had a calving to last service interval of 96 days (with $90 \%$ between 47 and 173 days). Those with COD had calving to last service interval of 116 days (with 90\% between 61 and 193 days). For cows which did not calve again (removed or culled) the corresponding figures were 114 (48 and 219) days, and 131 (59 and 238) days, respectively.

The distribution of parity, calving season, geographic distribution, number of offspring, lactations ending in calving or removal, and the recorded number of COD for each category are presented in Table 2 .
The incidence of COD was associated with herd size. Herds with the lowest incidence of COD were those with 35-85 cows per annum. The regions had similar patterns of COD occurrence throughout the year. The highest incidence was in autumn calving cows.

The distances from calving to first and second COD recording, as well as the distances between first and second COD in parities 1, 2 and above 2 are presented in Table 1 . The proportion of lactations with COD stratified by culling and if they had COD diagnosed in the previous lactation, is presented in Table 3. Of those cows that were culled, the farmers gave the primary reason for culling to be reproductive problems for 827 cows $(39.1 \%)$ for those that had COD, and 32,378 (13.8\%) for those without COD. Where given the corresponding figures for the secondary reason of culling were 89 (4.2\%) and 2668 (1.1\%), respectively.

The multivariable Cox survival model confirmed associations between COD occurrence and COD in previous lactation, parity, herd size, calving season as well as interactions between parity and calving season, and geographical region (Table 4). There was no association to twin or singleton at birth before COD diagnosis. The interaction between calving season and geographical region approached significance $(P=0.07)$, and so removed from the final model. The interaction between parity and season was highly significant with much higher COD risk in higher parities for cows calved during the autumn.

Results from the multivariable logistic regression model describing the risks of giving birth to twins were: twins or singleton at the start of lactation, parity, COD occurrence, region and calving season, in this ranking order according to Chi-square values. Herd had a small cluster effect. The detailed results are presented in Table 5. The lactations with COD had an OR $=2.2$ $(1.7-2.7)$ of having twins at the next calving compared to lactations without COD.

Results from the multivariable Cox survival model describing the hazards for removal from the herd were (in order of importance, $P<0.001$ for all variables): parity, singleton or twin at lactation start, calving season, herd size, region and finally COD in previous lactation, but not so in present lactation. Detailed estimates are presented in Table 6. The lactations with COD the previous lactation had a HR $=1.2(1.0-1.5)$ of ending in removal in $2^{\text {nd }}$ lactation compared to lactations without COD.

Results from the multivariable model describing the hazards for removal from the herd due to reproductive problems revealed the following hazards (in order of importance): COD both in the previous and the present lactation, calving season, region, twins or singleton at birth and herd size. Detailed estimates are presented in 
Table 2 Distribution of lactations with cystic ovarian disease by parity, calving season, geographic distribution and culling

\begin{tabular}{|c|c|c|c|c|}
\hline Variable & Class & N lactations & $\mathrm{n}$ & COD \% \\
\hline Total material & & 597,722 & 4,758 & 0.82 \\
\hline \multirow[t]{5}{*}{ Parity } & 1 & 213,006 & 845 & 0.40 \\
\hline & 2 & 153,532 & 1251 & 0.81 \\
\hline & 3 & 99,647 & 1211 & 1.21 \\
\hline & 4 & 56,706 & 780 & 1.36 \\
\hline & $>4$ & 53,073 & 671 & 1.25 \\
\hline \multirow[t]{4}{*}{ Calving season } & December, January, February & 115,394 & 834 & 0.72 \\
\hline & March, April, and May & 135,188 & 525 & 0.39 \\
\hline & June, July and August & 141,096 & 1,025 & 0.72 \\
\hline & September, October, and November & 183,356 & 2,374 & 1.28 \\
\hline \multirow[t]{7}{*}{ Geographic distribution } & Østfold, Akershus, Vestfold & 27,751 & 132 & 0.47 \\
\hline & Hedmark, Oppland, and Buskerud & 118,559 & 1,109 & 0.93 \\
\hline & Telemark, and Agder & 22,330 & 130 & 0.58 \\
\hline & Rogaland & 99,651 & 635 & 0.63 \\
\hline & Hordaland, Sogn og Fjordane & 68,616 & 649 & 0.94 \\
\hline & Møre og Romsdal and Trøndelag & 181,556 & 1,635 & 0.89 \\
\hline & Nord-Norge & 56,451 & 468 & 0.82 \\
\hline \multirow[t]{2}{*}{ Lactation ended with: } & New calving & 340,498 & 2,643 & 0.77 \\
\hline & Culling & 234,466 & 2,115 & 0.89 \\
\hline
\end{tabular}

Table 7. Of the lactations ending in removal, those with COD had a $\mathrm{HR}=1.4$ to 2.1 of ending lactation due to reproduction problems compared with ending the lactation due to other reasons in the $1^{\text {st }}$ to $>2^{\text {nd }}$ parity, respectively.

\section{Discussion}

The incidence of COD in Norwegian Red cattle was found to be lower than the figure previously presented by Østerås et al. [19]. This could be, in part, due to a real decrease from 2005 to 2008, but it could also be

Table 3 Lactations with cystic ovarian disease by diagnosis in previous lactation, stratified by culling

\begin{tabular}{lllll}
\hline $\begin{array}{l}\text { Calved } \\
\text { again }\end{array}$ & $\begin{array}{l}\text { COD or not in } \\
\text { previous lactation }\end{array}$ & $\begin{array}{l}\text { COD in next } \\
\text { lactation }\end{array}$ & $\mathbf{N}^{*}$ & Percentage \\
\hline Yes & Yes & Yes & 78 & 12.6 \\
& \multirow{2}{*}{ No } & No & 543 & 87.4 \\
& & Yes & 2,043 & 1.0 \\
& No & 200,849 & 99.0 \\
\hline Sum & & Yes & 2,121 & 1.0 \\
& & No & 201,392 & 99.0 \\
\hline No & Yes & Yes & 60 & 9.3 \\
& \multirow{2}{*}{ No } & No & 588 & 90.7 \\
& & Yes & 1,732 & 1.1 \\
& & No & 159,978 & 98.9 \\
\hline Sum & & Yes & 1,792 & 1.1 \\
& & No & 160,566 & 98.9 \\
\hline
\end{tabular}

* First parity excluded due to calculation differences. This study reports incidence per lactation, whilst the earlier study reports incidence per 100 cow years.

\section{Definition}

Older review papers define, COD as "anovulatory, follicular structures more than or equal to $2.5 \mathrm{~cm}$ in diameter that persists for more than 10 days", some include additional criteria such as "in absence of luteal tissue" $[2,3,23]$. However, during the last decade the following definition has gained popularity: Ovarian follicle cysts at least $17 \mathrm{~mm}$ in diameter and persist for more than 6 days with no corpus luteum detectable by ultrasound [1]. The term COD should be reconsidered as the cystic follicles generally occur without obvious clinical signs [12]. The current study is based on the field work of practicing veterinary surgeons. Under these conditions repeat examination of the ovaries to see if the COD lasted for more than 10 days was not practical; therefore the NCHS definition was used.

The diagnoses in this study were mainly made by manual rectal ovarian palpation and they may have been the result of a scheduled examination, in a reproductive herd health programme, or because the farmer wanted a specific cow examined. Either way the identification of COD is strongly dependent on individual farmer's use of veterinary services. It is, therefore, important to include the random herd effect in the models. Consequentially, it is likely this study has a substantial degree of 
Table 4 Estimated hazard ratio from the multivariable Cox regression model with time of cystic ovarian disease (COD) diagnosis between day $\mathbf{4 0}$ and 146 in lactation and herd as cluster

\begin{tabular}{|c|c|c|c|c|}
\hline Variable & Class & $\mathbf{N}$ & Chi-square & HR $(95 \% \mathrm{Cl})$ \\
\hline \multirow[t]{2}{*}{ COD recorded during previous lactation } & No & 510,565 & - & 1.0 \\
\hline & Yes & 1,092 & 364.3 & $7.5(6.1-9.3)$ \\
\hline \multirow[t]{12}{*}{ Interaction parity and calving season } & $1^{\text {st }}$ and spring & 35,969 & - & 1,0 \\
\hline & $1^{\text {st }}$ and summer & 45,126 & 24.7 & $2.1(1.6-2.8)$ \\
\hline & $1^{\text {st }}$ and autumn & 64,667 & 44.8 & $2.6(1.9-3.4)$ \\
\hline & $1^{\text {st }}$ and winter & 40.776 & 11.0 & $1.7(1.2-2.3)$ \\
\hline & $2^{\text {nd }}$ and spring & 32.530 & 7.3 & $1.6(1.1-2.2)$ \\
\hline & $2^{\text {nd }}$ and summer & 31,007 & 72.4 & $3.5(2.6-4.7)$ \\
\hline & $2^{\text {nd }}$ and autumn & 43,755 & 168.8 & $6.1(4.6-7.9)$ \\
\hline & $2^{\text {nd }}$ and winter & 29,121 & 85.7 & $3.9(2.9-5.2)$ \\
\hline & $>2^{\text {nd }}$ and spring & 50,802 & 43.5 & $2.6(2.0-3.4)$ \\
\hline & $>2^{\text {nd }}$ and summer & 45,134 & 148.4 & $5.5(4.2-7.3)$ \\
\hline & $>2^{\text {nd }}$ and autumn & 56,931 & 300,0 & $10.2(7.8-13.2)$ \\
\hline & $>2^{\text {nd }}$ and winter & 32,840 & 146.1 & $5.5(4.1-7.2)$ \\
\hline \multirow[t]{3}{*}{ Herd size } & $<35$ & 430,962 & 15.8 & $1.4(1.2-1.6)$ \\
\hline & 35 to 84 & 75,430 & - & 1.0 \\
\hline & $>84$ & 5,265 & 7.7 & $2.0(1.2-3.3)$ \\
\hline \multirow[t]{3}{*}{ Region } & $<60^{\circ}$ latitude & 131,159 & - & 1.0 \\
\hline & 60 to $65^{\circ}$ & 329,186 & 21.6 & $1.3(1.2-1.5)$ \\
\hline & $>65^{\circ}$ & 51,312 & 6.1 & $1.2(1.0-1.4)$ \\
\hline
\end{tabular}

underreporting, because farmers do not present all cows with COD for veterinary examination. The study may have misclassified lactations in which COD was not detected. Currently the use of regular fertility examinations is sporadic in Norway and, as such, this paper probably reflects the extent to which COD is causing reproductive problems in the Norwegian dairy production. It is important to remember that normal follicular activity may have been incorrectly diagnosed as COD. Early developing corpora lutea, and some corpora lutea of pregnancy, are soft and can be misdiagnosed as cysts by manual rectal palpations [5].

The authors consider that the lack of diagnoses occurred more frequently than wrong diagnosis of COD

Table 5 Estimates from the multivariable logistic model of having twins versus singleton as dependent variable

\begin{tabular}{lllll}
\hline Variable & Class & $\mathbf{N}$ & Estimate (stderr) & OR (95\% Cl) \\
\hline Intercept & & 156,661 & $-3.39(0.04)$ & 1.0 \\
Parity & 1 & 63,038 & 0.00 & $1.2(1.1-1.3)$ \\
& 2 & 44,182 & $0.20(0.04)$ & $1.4(1.3-1.5)$ \\
Diagnosis of COD during lactation & $>2$ & 49,441 & $0.32(0.03)$ & 1.0 \\
& No & 155,455 & 0.00 & $2.2(1.7-2.7)$ \\
Lactation start with & Yes & 1,206 & $0.77(0.11)$ & 1.0 \\
& Singleton & 147,096 & 0.00 & $3.0(2.6-3.4)$ \\
& Twins & 2902 & $1.09(0.07)$ & $4.3(0.5-39)$ \\
Calving season & Triplets & 7 & $1.46(1.12)$ & $1.1(0.9-1.2)$ \\
& Others* & 6,656 & $0.05(0.07)$ & 1.0 \\
& March-May (spring) & 37,141 & 0.00 & $0.9(0.8-0.9)$ \\
Region & September-November (autumn) & 49,171 & $-0.14(0.04)$ & $0.9(0.8-1.0)$ \\
& December-February (winter) & 30,545 & $-0.08(0.04)$ & $1.1(1.0-1.2)$ \\
Herd effect & June-August (summer) & 39,804 & $0.06(0.04)$ & 1.0 \\
\hline
\end{tabular}

* Lactations starting with an abortion or lactations starting with calving prior to the date the cow was introduced into the present herd 
Table 6 Estimated hazard ratio from the multivariable Cox regression model with time at culling as the dependent variable and herd as cluster. COD = cystic ovarian disease

\begin{tabular}{|c|c|c|c|c|c|c|c|c|c|c|}
\hline & & $\begin{array}{l}1^{\text {st }} \\
\text { parity }\end{array}$ & & & $\begin{array}{l}2^{\text {nd }} \\
\text { parity }\end{array}$ & & & $\begin{array}{l}>2^{\text {nd }} \\
\text { parity }\end{array}$ & & \\
\hline Variable & Class & $N$ & $\begin{array}{l}\text { Chi- } \\
\text { square }\end{array}$ & HR $(95 \% \mathrm{Cl})$ & $\mathrm{N}$ & $\begin{array}{l}\text { Chi- } \\
\text { square }\end{array}$ & HR $(95 \% \mathrm{Cl})$ & $N$ & $\begin{array}{l}\text { Chi- } \\
\text { square }\end{array}$ & HR $(95 \% \mathrm{Cl})$ \\
\hline \multirow{2}{*}{$\begin{array}{l}\text { COD recorded during } \\
\text { previous lactation }\end{array}$} & No & 197,900 & - & - & 144,464 & - & 1.0 & 199,409 & - & 1.0 \\
\hline & Yes & 0 & - & - & 256 & 3.7 & $1.22(1.00-1.49)$ & 952 & 18.7 & $1.22(1.12-1.34)$ \\
\hline \multirow{2}{*}{$\begin{array}{l}\text { COD recorded during } \\
\text { present lactation }\end{array}$} & No & 197,105 & - & 1.0 & 143,517 & - & 1.0 & 197,792 & - & 1.0 \\
\hline & Yes & 795 & 1.8 & $0.91(0.80-1.04)$ & 1,203 & 2.3 & $1.07(0.98-1.17)$ & 2,569 & 59.2 & $0.79(0.75-0.84)$ \\
\hline \multirow[t]{2}{*}{ Twins or triplets } & No & 196,303 & - & 1.0 & 140,825 & - & 1.0 & 192,986 & - & 1.0 \\
\hline & Yes & 1,597 & 5.2 & $1.11(1.02-1.22)$ & 3,895 & 67.6 & $1.25(1.19-1.32)$ & 7,375 & 162.2 & $1.25(1.20-1.29)$ \\
\hline \multirow[t]{4}{*}{ Calving season } & Spring & 38,384 & 103.7 & $1.17(1.14-1.21)$ & 33,772 & 2.9 & $1.03(1.00-1.06)$ & 54,731 & 4.3 & $1.02(1.00-1.05)$ \\
\hline & Summer & 47,907 & - & 1.0 & 35,491 & - & 1.0 & 48,959 & - & 1.0 \\
\hline & Autumn & 68,261 & 20.5 & 1.07 (1.04-1.09) & 45,229 & 23.5 & $0.93(0.91-0.96)$ & 61,351 & 71.6 & $0.92(0.90-0.93)$ \\
\hline & Winter & 43,348 & 183.9 & $1.22(1.19-1.26)$ & 30,228 & 25.2 & $1.08(1.05-1.11)$ & 35,320 & 35.7 & $1.07(1.05-1.10)$ \\
\hline \multirow[t]{3}{*}{ Herd size } & $<35$ & 165,420 & - & 1.0 & 121,395 & - & n.s & 169,781 & - & n.s \\
\hline & 35 to 84 & 30,489 & 7.9 & $1.06(1.02-1.10)$ & 21,834 & - & n.s. & 28,555 & - & n.s. \\
\hline & $>84$ & 2,047 & 0.4 & $1.06(0.88-1.27)$ & 1,536 & - & n.s. & 2,088 & - & n.s. \\
\hline \multirow[t]{3}{*}{ Region } & $\begin{array}{l}<60^{\circ} \\
\text { latitude }\end{array}$ & 53,392 & 34.0 & 1.15 (1.10-1.20) & 37,822 & 22.3 & $1.11(1.06-1.16)$ & 49,708 & 10.8 & $1.06(1.02-1.09)$ \\
\hline & 60 to $65^{\circ}$ & 125,037 & 8.1 & $1.06(1.02-1.11)$ & 92,371 & 1.4 & $1.02(0.99-1.06)$ & 130,883 & 0.4 & $1.01(0.98-1.04)$ \\
\hline & $>65^{\circ}$ & 19,471 & - & 1.0 & 14,527 & - & 1.0 & 19,770 & - & 1.0 \\
\hline
\end{tabular}

in this study. Therefore the 'true' incidence of COD in the Norwegian Red is likely to be higher than reported in this paper, particularly as spontaneous recovery from COD occurs $[11,23]$. Furthermore, we consider that the diagnoses used in the current study will have a low sensitivity and a much higher specificity. The positive value of both follicular and luteal cysts diagnosed by manual rectal palpation has been reported to be $66 \%$, compared to $75 \%$ and $85 \%$, respectively, when diagnosis is made with the aid of transrectal ultrasonography [24]. If exposure variables were associated with herd, this could lead to different misclassification in different exposure groups. Such misclassification could lead to wrong interpretation of the results. However, in this study we consider the exposure variables parity, herd size, season and latitude to be independent of farmer. Therefore the misclassification bias should not be large. However, each misclassification will lead to a loss of statistical power in the analyses, and may result in a failure to identify associations. The authors consider the chance of missing associations in this study greater than the chance of identifying wrong associations. The size of the material will improve the study's power, assuming a lack of selection bias.

This study reflects the understanding of COD as experienced in the field, and shows the real effect of the diagnosis and treatment veterinary surgeons are performing. A further strength of this study is that the cows are examined in their every day environment and not under constructed or artificial conditions which may cause the animals stress, a possible risk factor for the disease [25-29].

\section{Statistical model}

The cow population is very dynamic, demonstrated in this study by a herd removal rate of $40.8 \%$. Given this fact, survival analysis was chosen as statistical method to be used for model with hazard having COD, culling and culling due to reproduction in the analyses, as it accounts for censored data. However, as cows within the same herd are not independent of each other, the marginal Cox model for clustered data was applied. For the hazard estimate of twins associated with COD alternative logistic regression was used [22] with herd included as a random effect to account for the dependency between observations within the same herd. To reduce possible selection bias the lactation period of estimating associations to COD was restricted to 40 to 165 DIM. For the culling models we tested if the results were different when the start of observation was changed from day of calving to 40 DIM or 150 DIM. All these test models were consistent with the published models. Therefore, we consider that the chosen starting point affect the results minimally 
Table 7 Estimated hazard ratio from the multivariable Cox regression model with time at culling due to reproductive problems amongst only culled cows and herd as cluster

\begin{tabular}{|c|c|c|c|c|c|c|c|c|c|c|}
\hline & & $\begin{array}{l}1^{\text {st }} \\
\text { parity }\end{array}$ & & & $\begin{array}{l}2^{\text {nd }} \\
\text { parity }\end{array}$ & & & $\begin{array}{l}>2^{\text {nd }} \\
\text { parity }\end{array}$ & & \\
\hline Variable & Class & $\mathrm{N}$ & $\begin{array}{l}\text { Chi- } \\
\text { square }\end{array}$ & HR $(95 \% \mathrm{Cl})$ & $\mathrm{N}$ & $\begin{array}{l}\text { Chi- } \\
\text { square }\end{array}$ & HR $(95 \% \mathrm{Cl})$ & $\mathrm{N}$ & $\begin{array}{l}\text { Chi- } \\
\text { square }\end{array}$ & HR $(95 \% \mathrm{Cl})$ \\
\hline \multirow{2}{*}{$\begin{array}{l}\text { COD recorded during } \\
\text { previous lactation }\end{array}$} & No & 50,375 & & & 42,601 & n.s & & 81,680 & - & 1.0 \\
\hline & Yes & 0 & & & 90 & n.s & & 442 & 14.2 & $1.56(1.24-1.97)$ \\
\hline \multirow{2}{*}{$\begin{array}{l}C O D \text { recorded during } \\
\text { present lactation }\end{array}$} & No & 50,173 & - & 1.0 & 42,288 & - & 1.0 & 81,169 & - & 1.0 \\
\hline & Yes & 202 & 11.9 & $1.38(1.15-1.66)$ & 403 & 45.3 & $1.68(1.45-1.96)$ & 953 & 178.3 & $2.06(1.85-2.29)$ \\
\hline \multirow[t]{2}{*}{ Twins or triplets } & No & 49,927 & n.s & & 41,302 & - & 1.0 & 78,539 & n.s & \\
\hline & Yes & 448 & n.s & & 1,389 & 4.8 & $1.15(1.01-1.30)$ & 3,583 & n.s & \\
\hline \multirow[t]{4}{*}{ Calving season } & Spring & 10,328 & - & 1.0 & 10,229 & - & 1.0 & 23,002 & - & 1.0 \\
\hline & Summer & 11,027 & 31.9 & $1.24(1.15-1.35)$ & 10,275 & 19.4 & $1.18(1.10-1.27)$ & 19,862 & 46.1 & $1.27(1.18-1.36)$ \\
\hline & Autumn & 16,890 & 1.1 & $1.04(0.97-1.11)$ & 12,597 & 1.8 & $1.05(0.98-1.12)$ & 23,706 & 8.0 & $1.10(1.03-1.17)$ \\
\hline & Winter & 12,130 & 2.8 & $1.06(0.99-1.14)$ & 9,590 & 0.5 & $1.02(0.95-1.10)$ & 15,552 & 2.7 & $1.06(0.99-1.13)$ \\
\hline \multirow[t]{3}{*}{ Region } & $<60^{\circ}$ latitude & 14,113 & 0.5 & $1.04(0.94-1.15)$ & 11,720 & 0.2 & $0.98(0.88-1.09)$ & 21,059 & 10.5 & $1.19(1.07-1.33)$ \\
\hline & 60 to $65^{\circ}$ & 31,567 & 7.7 & $1.14(1.04-1.25)$ & 26,789 & 6.7 & $1.14(1.03-1.26)$ & 52,941 & 18.6 & $1.24(1.12-1.36)$ \\
\hline & $>65^{\circ}$ & 4,695 & - & 1.0 & 4,182 & - & 1.0 & 8,122 & - & 1.0 \\
\hline
\end{tabular}

COD = cystic ovarian disease.

\section{Risk Factors Parity}

The likelihood of COD occurrence increases with parity. This may be the result of other pathological and physiological conditions which are related to increasing parity, e.g. milk fever [30]. Another factor may be selection bias, a farmer choosing to keep high yielding cows as long as possible in the herd [3,31]. Some studies have shown a correlation between high milk yield and COD occurrence $[3,6]$ but other studies disagree [9,32,33]. Interestingly the occurrence of COD in animals in their third lactation or more is preventive for culling despite the reduced reproductive performance in these animals. This means that these animals must have other traits which the farmer values over and above the reduction in reproductive performance, e.g. high milk yield.

\section{$C O D$ in the preceding lactation}

Cows which experienced COD in their last lactation have a considerably higher hazard of suffering COD in the present lactation. This is understandable as there is evidence that COD is associated with the cow's genetics and environment [12]. However, when a decision is been taken as to whether to cull a cow that has COD or not, and when calculating the costs of the disease, the increased hazard of reoccurrence should be included.

\section{Herd size}

This study has demonstrated a correlation between herd size and COD occurrence. Cattle are gregarious animals with a diurnal rhythm and housing them can limit their natural behaviour. The exact effect of sub-optimal housing is not known, but a negative correlation with reproduction, including COD occurrence, is presumed. Simensen, et al. [16] found more COD diagnoses in free-stalls compared to tie-stalls [16]. Free-stalls are more frequent in larger herds. Hence, the identified herd size effect in the study could be an effect of housing system. Unfortunately, the information of housing system was not available in this study. A Belgian study asserts the housing of cows is a significant risk. Their study showed a 5.7 greater risk of getting COD when calving indoors compared to pasture calving [34].

\section{Season}

This study has shown that autumn calving increases COD occurrence, compared to calving in winter, spring and summer, which confirms the pattern found in Sweden in 1991 [18]. Cows would have their active reproduction period 40 to 170 days after calving according to this study. Thus, cows that calved during autumn will have their service period during the housed winter time. In tropical or hot regions there are reports of an opposite trend with more COD during summer [35,36], but studies from the USA did not find seasonality to be important $[9,37]$. However, to avoid or minimize stress for gregarious diurnal animals, light is important for daily tasks and for recognising herd mates. There is a higher culling rate due to reproductive problems for cows that calved during the autumn.

\section{Latitude}

Norway is a climatically and environmentally diverse country in which regional differences in COD occurrence could be expected. There was less COD south of $60^{\circ} \mathrm{N}$ compared to north of $60^{\circ} \mathrm{N}$. North of $65^{\circ} \mathrm{N}$ there is 
constant daylight during the summer and no daylight during the winter. Despite farmers having artificial lighting, effects on reproductive performance do exist [17]. There could also be other differences between southern and northern Norway which explain this association, such as feed quality, feeding strategy, length of pasture time, etc. Moreover, it is interesting to observe that there is a seasonal as well as a latitude effect. Heat stress as observed in Spain[11] could also occur in Norway during summer, but not to the same extent as in Spain or other southern European countries.

\section{Twins}

The correlation between COD occurrence and singleton vs. twin calving supports the earlier study of Emmanuelson and Bendixen [18] which concluded that there is an increased risk of twinning after a COD occurrence. Silvia et al. have found that $47 \%$ of cows had two or more persistent follicles at the time of first detection $[1,14]$, which also might explain the correlation between COD and twinning. Kinsel et al. [14] also found that increasing milk yield over time is the most important risk factor for twinning [14], and as described earlier, there is a correlation between milk yield and COD occurrence. Furthermore, in the present study, the association of twins is opposite directed with both season and latitude, compared to the association with COD. This point at different mechanisms, as there are less twins with cows calved during autumn and cows north of $60^{\circ} \mathrm{N}$, while there are more COD. There is also a small herd effect for twins.

\section{Removal/culling}

The reason for the greater relative percentage of cows with COD in the cows being culled, compared to those staying in the herd may be because the COD occurrence is a considerable part of the reproductive problem. This was also confirmed in this study, using the given descriptive reason by the farmer in the analyses and concurs with the findings of Refsdal [38]. Norwegian herds also have a relatively high replacement percentage, and cows showing any abnormalities, e.g. COD occurrence [39], or poor milk yield are preselected as culling candidates, as these cows may have problems with getting pregnant at economic feasible time in lactation.

\section{Conclusion}

Cows in higher parity have an increased risk of being diagnosed with COD. Cows treated for COD in one lactation have an increased risk of having a COD diagnosed in the following lactation. This study also illustrates that autumn calving in Norway is associated with higher risk of COD, especially for cows in higher parities. Cows with COD diagnosis had higher risk of giving birth to twins. Cows north of $60^{\circ} \mathrm{N}$ had higher risk of COD, and a lower risk of giving birth to twins.
Season is associated in the opposite direction with twinning compared to the association COD. Cows treated for COD in the previous lactation had higher hazard for culling and those who were culled had a higher hazard of culling due to reproductive problems.

\section{Acknowledgements}

Access to the data was provided by the Norwegian Dairy Herd Recording System (NDHRS) and the Norwegian Cattle Health Services (NCHS) according to agreement number $1 / 2008$ of $29^{\text {th }}$ February 2008. The Section for Herd Health and Field Service, Norwegian School of Veterinary Science, is acknowledged for providing financial support for this study.

\section{Authors' contributions}

STN, ADM and $O \varnothing$ have performed this work as a part of STN's European College of Bovine Health Management residency programme. All authors were involved in the study design, interpretation of results and drawing of conclusions. $O \varnothing$ performed the main statistical analyses, and STN was the head writer of the manuscript. All authors have been active in writing this paper and read and approved the final manuscript.

\section{Competing interests}

The authors declare that they have no competing interests.

Received: 9 July 2010 Accepted: 8 November 2010

Published: 8 November 2010

\section{References}

1. Silvia WJ, Hatler TB, Nugent AM, Laranja da Fonseca LF: Ovarian follicular cysts in dairy cows: an abnormality in folliculogenesis. Domest Anim Endocrinol 2002, 23:167-177.

2. Garverick HA: Ovarian follicular cysts in dairy cows. J Dairy Sci 1997, 80:995-1004.

3. Laporte HM, Hogeveen H, Schukken YH, Noordhuizen JPTM: Cystic ovarian disease in Dutch dairy-cattle .1. Incidence, risk-factors and consequences. Livestock Prod Sci 1994, 38:191-197.

4. Grunert $\mathrm{E}$, de Kruif A: Fertilitätsstörungen beim weiblichen Rind Parey Buchverlag, Blackwell Wissenschafts-Verlag GmbH; 1999.

5. Youngquist $\mathrm{R}$, Threlfall $\mathrm{W}$ : Current therapy in large animal theriogenology Elsevier; 2006

6. Hooijer GA, Lubbers RBF, Ducro BJ, van Arendonk JAM, KaalLansbergen LMTE, van der Lende T: Genetic parameters for cystic ovarian disease in Dutch Black and White dairy cattle. J Dairy Sci 2001, 84:286-291.

7. Fourichon C, Seegers H, Bareille N, Beaudeau F: Effects of disease on milk production in the dairy cow: a review. Prev Vet Med 1999, 41:1-35.

8. Emanuelson U, Oltenacu PA: Incidences and effects of diseases on the performance of Swedish dairy herds stratified by production. J Dairy SCi 1998, 81:2376-2382.

9. Bartlett PC, Ngategize PK, Kaneene JB, Kirk JH, Anderson SM, Mather EC: Cystic follicular disease in Michigan Holstein-Friesian cattle - incidence, descriptive epidemiology and economic-impact. Prev Vet Med 1986, 4:15-33.

10. De Vries A, Crane MB, Bartolome JA, Melendez P, Risco CA, Archbald LF: Economic comparison of timed artificial insemination and exogenous progesterone as treatments for ovarian cysts. J Dairy Sci 2006 89:3028-3037.

11. López-Gatius F, Santolaria P, Yániz J, Fenech M, López-Béjar M: Risk factors for postpartum ovarian cysts and their spontaneous recovery or persistence in lactating dairy cows. Theriogenology 2002, 58:1623-1632.

12. Vanholder T, Opsomer G, de Kruif A: Aetiology and pathogenesis of cystic ovarian follicles in dairy cattle: a review. Reprod Nutr Dev 2006, 46:105-119.

13. Bendixen PH, Oltenacu PA, Andersson L: Case-referent tudy of cystic ovaries as a risk indicator for twin calvings in dairy-cows. Theriogenology 1989, 31:1059-1066.

14. Kinsel ML, Marsh WE, Ruegg PL, Etherington WG: Risk factors for twinning in dairy cows. J Dairy Sci 1998, 81:989-993. 
15. Nielen M, Schukken YH, Scholl DT, Wilbrink HJ, Brand A: Twinning in dairycattle - A study of risk-factors and effects. Theriogenology 1989, 32:845-862.

16. Simensen $\mathrm{E}$, Østerås $\mathrm{O}$, Bøe KE, Kielland $\mathrm{C}$, Ruud LE, Næss G: Housing system and herd size interactions in Norwegian dairy herds; associations with performance and disease incidence. Acta Vet Scand 2010, 52:14.

17. Reksen O, Tverdal A, Landsverk K, Kommisrud E, Bøe KE, Ropstad E: Effects of photointensity and photoperiod on milk yield and reproductive performance of Norwegian Red cattle. J Dairy Sci 1999, 82:810-816.

18. Emanuelson $\mathrm{U}$, Bendixen PH: Occurrence of cystic ovaries in dairy-cows in Sweden. Prev Vet Med 1991, 10:261-271.

19. Østerås O, Solbu H, Refsdal AO, Roalkvam T, Filseth O, Minsaas A: Results and evaluation of thirty years of health recordings in the Norwegian dairy cattle population. J Dairy Sci 2007, 90:4483-4497.

20. Lee EW, Wei $\amalg$, Amato DA: Cox-type regression analysis for large numbers of small groups of correlated failure time observations. In Survival analysis: State of the art. Volume 211. Edited by: Klein JP, Goel PK. Dordrecht: Kluwer Academic Publishers; 1992:237-247.

21. Allison PD: Survival analysis using SAS system: A practical guide Cary: SAS Institute Inc; 2010

22. Carey V, Zeger SL, Diggle P: Modeling multivariate binary data with alternating logistic regressions. Biometrika 1993, 80:517-526.

23. Kesler DJ, Garverick HA: Ovarian cysts in dairy-cattle - A review. J Anim Sc 1982, 55:1147-1159.

24. Hanzen C, Pieterse M, Scenczi O, Drost M: Relative accuracy of the identification of ovarian structures in the cow by ultrasonography and palpation per rectum. Vet J 2000, 159:161-170.

25. Dobson H, Smith RF: Stress and reproduction in farm-animals. J Reprod Fert 1995, 451-461.

26. Dobson H, Smith RF: Stress and subfertility. Reprod Domest Anim 1998, 33:107-111.

27. Dobson H, Ribadu AY, Noble KM, Tebble JE, Ward WR: Ultrasonography and hormone profiles of adrenocorticotrophic hormone (ACTH)-induced persistent ovarian follicles (cysts) in cattle. J Reprod Fertil 2000, 120:405-410.

28. Dobson H, Tebble JE, Smith RF, Ward WR: Is stress really all that important? Theriogenology 2001, 55:65-73.

29. Zulu VC, Penny C: Risk factors of cystic ovarian disease in dairy cattle. $J$ Reprod Dev 1998, 44:191-195.

30. Fleischer $\mathrm{P}$, Metzner $\mathrm{M}$, Beyerbach $\mathrm{M}$, Hoedemaker $\mathrm{M}$, Klee W: The relationship between milk yield and the incidence of some diseases in dairy cows. J Dairy Sci 2001, 84:2025-2035.

31. Dohoo IR, Martin SW: Disease, production and culling in Holstein-Friesian cows .5. survivorship. Prev Vet Med 1984, 2:771-784.

32. Uribe HA, Kennedy BW, Martin SW, Kelton DF: Genetic parameters for common health disorders of Holstein cows. J Dairy Sci 1995, 78:421-430.

33. Johnson $A D$, Legates JE, Ulberg LC: Relationship between follicular cysts and milk production in dairy cattle. J Dairy Sci 1966, 49:865-868.

34. Opsomer G, Gröhn YT, Hertl J, Coryn M, Deluyker H, de Kruif A: Risk factors for post partum ovarian dysfunction in high producing dairy cows in Belgium: A field study. Theriogenology 2000, 53:841-857.

35. Ron M, Bar-Anan R, Wiggans GR: Factors affecting conception rate of Israeli Holstein cattle. J Dairy Sci 1984, 67:854-860.

36. Zeron Y, Ocheretny A, Kedar O, Borochov A, Sklan D, Arav A: Seasona changes in bovine fertility: relation to developmental competence of oocytes, membrane properties and fatty acid composition of follicles. Reproduction 2001, 121:447-454.

37. Scholl DT, BonDurant RH, Farver TB: Eleven-year analysis of changes in the incidence and recurrence of cystic ovarian disease in a herd of dairy cattle in California. Am J Vet Res 1990, 51:314-319.

38. Refsdal AO: Undersøkelse av kviger og kyr utsjaltet på grunn av ufruktbarhet (Studies on cows and heifers culled due to infertility). PhD Thesis Norwegian College of Veterinary Medicine; 1979, 184, (In Norwegian, with English summary).

39. Martin SW, Aziz SA, Sandals WCD, Curtis RA: The association between clinical-disease, production and culling of Holstein-Friesian cows. Can $J$ Anim Sci 1982, 62:633-640.

doi:10.1186/1751-0147-52-60

Cite this article as: Nelson et al:: Risk factors associated with cystic ovarian disease in Norwegian dairy cattle. Acta Veterinaria Scandinavica 2010 52:60.

\section{Submit your next manuscript to BioMed Central and take full advantage of:}

- Convenient online submission

- Thorough peer review

- No space constraints or color figure charges

- Immediate publication on acceptance

- Inclusion in PubMed, CAS, Scopus and Google Scholar

- Research which is freely available for redistribution

Submit your manuscript at www.biomedcentral.com/submit
Biomed Central 